\title{
STATISTICAL DATA FOR CERVICAL CANCER SCREENING FROM 2016 - 2020 AND AMBULATORY AND DISPENSARY MORBIDITY FROM 2011 - 2020 FOR KOCANI, VINICA, BEROVO, PEHCEVO AND DELCEVO
}

\author{
Jihe Zhu ${ }^{1} \rrbracket$, Blagica Arsovska 1,2, Kristina Kozovska 1,3 \\ ${ }^{1}$ Faculty of Medical Sciences, University Goce Delchev, Shtip, Republic of Macedonia. \\ ${ }^{2}$ Institute of Biology, Faculty of Natural Sciences and Mathematics, Skopje, Republic of Macedonia. \\ ${ }^{3}$ Medicine Faculty, St. Cyril And Methodius University of Skopje, Republic of Macedonia.
}

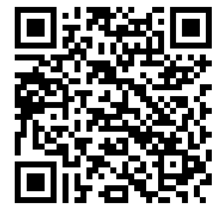

Received 9 July 2021

Accepted 21 August2021

Published 31 August 2021

CorrespondingAuthor

Kristina Kozovska,

tongdatang-tcm@hotmail.com

DOI

10.29121/granthaalayah.v9.i8.2021. 4185

Funding: This research received no specific grant from any funding agency in the public, commercial, or not-for-profit sectors.

Copyright: (C) 2021 The Author(s). This is an open access article distributed under the terms of the Creative Commons Attribution License, which permits unrestricted use, distribution, and reproduction in any medium, provided the original author and source are credited.

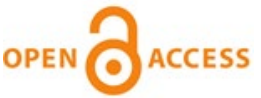

\section{ABSTRACT}

Each year, more than half a million women are diagnosed with cervical cancer, resulting in about 300,000 deaths a year. In Macedonia cervical cancer is second most common according to the prevalence of malignant neoplasms in women. The most common and most studied cause is Human Papillomavirus (HPV). For the research were used statistical materials obtained from Center for Public Health - Kocani and State Statistical Office of R. Northern Macedonia. For the collected data from the organized screening on the territory of Kocani, Vinica, Berovo, Pehchevo and Delchevo for the period 2016-2020, as well as reported outpatient polyclinic morbidity for the same territory in a period of 10 years, ie from 2011 - 2020, was used statistical method. Screening with Pap smear is the best method to decrease the number of cervical cancer diseased and decrease mortality. Preliminary results from new immunotherapy approaches show promising results for overall survival. The main purpose of this research is to point out the importance of regular examinations and screening for early detection of cervical changes, prevention of invasive forms of cancer, and timely treatment.

Keywords: Cervix, Cancer, HPV, Screening, Prevention

\section{INTRODUCTION}

Cervical cancer remains a public health problem worldwide as it is responsible for the lives of approximately 300,000 women per year. In highly developed countries there are effective methods for early detection of precancerous lesions by cytology (PAP smear). Due to the weak health system, as well as limited resources for screening and treatment, the highest percentage of deaths are in undeveloped and in developing countries. It usually affects women who are in the reproductive and working period of life. The percentage of deaths can be avoided especially because there is a lot of evidence that cervical cancer is one of the most preventable forms of cancer and with a good prognosis if detected early and treated effectively (World Health Organization, 2014).

The primary cause of precancerous changes and squamous cell carcinoma is asymptomatic persistent or chronic infection with high-risk HPV type (oncogenic). The highest prevalence of high-risk HPV type is observed in young people and death from cervical cancer reaches a peak in the period of 40-50 years of age. Factors that can increase the risk of HPV infection and thus the development of cancer are having multiple partners as well as a partner who has had multiple partners. Although in the majority of cancers, the cause is mainly high-risk HPV infection, the presence of HPV does not always mean that the 
condition will progress to cancer. In fact, most women infected with HPV will not develop cancer regardless of the type of virus, because the virus lives short and the body eliminates it spontaneously over a period of two years. The infection persists in only a small percentage of women, of whom a small percentage develop precancerous lesions, and an even smaller percentage of them will progress to invasive cancer. There are cofactors which allow HPV infection to persist and progress to cancer. The most common of them are co-infection with other sexually transmitted agents such as herpes simplex, gonorrhea, chlamydia, parity and early age of first pregnancy, smoking, genetic factors, circumcision of the partner, use of oral contraceptives for more than five years, HPV type, immune status and other. It is important to note that the absence of HPV does not mean the absence of disease. All of the above factors not only condition the persistence of HPV infection, but also in the absence of infection, contribute to cervical changes. Unfortunately, most women remain asymptomatic until the disease progresses, especially women who are not sexually active at the time. Early symptoms include: increased bad-smelling vaginal discharge, irregular bleeding in women of childbearing potential, postcoital point bleeding, postmenopausal bleeding. Specific symptoms are not always present, but changes such as erythroplakia and leukoplakia will be seen on routine examination. When the disease has progressed and the tumor has spread to the surrounding organs and tissues, then symptoms characteristic of the affected tissues occurs. As the process deepens in the cervix, the bleeding becomes heavier and there is pain in the lower back, spine and legs. If the bladder is involved, the patient will have a feeling of urgency, dysuria, polyuria, hematuria.

The primary method by which changes can be detected as a result of high-risk HPV is PAP test. PAP is a screening tool that requires changes in the transformation zone and often those changes are caused by HPV. But not every woman who gets a positive screening test actually has cervical cancer. Additional diagnostic tests are performed after screening to confirm or rule out the diagnosis. Colposcopy, biopsy, and endocervical curettage are the most commonly used methods for diagnosing cervical cancer. Treatment should be individualized for each patient. The treatment plan is best to make a team of gynecologists, oncologists and radiotherapy specialists. Options for treating invasive cancer include surgery, radiotherapy, chemotherapy, or a combination of these. Early detection methods, in addition to cytology, include visual inspection of the cervix with Schiller test and acetoacetic acid staining and HPV DNA testing and typing. Lesions that are cytologically detected are CIN-marked cervical intraepithelial neoplasms and can be mild to dysplasia (CIN1), moderate (CIN2), severe (CIN3), or carcinoma in situ (CIS).

Prevention and control programs are most important and designed to reduce incidence, morbidity and mortality. Aref-Adib, M., Freeman-Wang, T., (2016), Bansal, A., Singh, M., Rai, B. (2016), Barek, C. J. (2011), Barret, K. E., Barman, S. M., Boitano, S., Brooks, H. L. (2012), Burd, E. M., (Jan., 2003), Dimitrov, G., Sterjovska Aleksovska, A., (2013), Hurt, K. J., Guile, M. W., Bienstock, J. L., Fox, H. E., Wallach, E. (2010), Jovanovski D., Maneva-Kostovska, L., Anastasova-Nikolova L., Smickoska, S., Krstevska, V., (2002), Kumar, V., Abbas, A. K., Aster, J. C. (2015), Ministry of Health of the Republic of Northern Macedonia. Guidelines for practicing evidence-based medicine (n.d.), Mladenovic, D. Et al. (2008), Palchevski, G. (1981).

\section{MATERIAL AND METHODS}

To achieve the objectives of this research, a statistical method of analysis was used on to collected data from the organized screenings on the territory of Kocani, Vinica, Berovo, Pehchevo and Delchevo for the period 2016-2020, as well as 
reported outpatient - polyclinic morbidity for the same territory in a period of 10 years, ie from 2011 - 2020.

The statistical materials were obtained from the Center for Public Health Kocani and the State Statistical Office of the Republic of Macedonia.

\section{RESULTS AND DISCUSSION}

In the research are processed the results of the conducted cervical cancer screenings on the territory of Kocani, Vinica, Berovo, Pehchevo and Delchevo for the period 2016-2020.

According to the Program for early detection of malignant diseases in the Republic of Northern Macedonia, at the national level, screening is performed by gynecologists from private health institutions in accordance with preventive measures prescribed by the HIF, and refers to women who have selected a gynecologist and followed the procedure for gynecological examination, taking on a swab, preparation and delivery of the material for cytological analysis.

The target group for screening are women aged 24-60. The recommended time interval for screening is 3 years. A still high percentage of women have limited access or no access to the Organized Screening Program at all because there are no gynecologists in their municipalities or there are not enough registered gynecologists. According to the Program for early detection of malignant diseases in the Republic of Macedonia for 2016 and the activities provided by the Program for Early Detection and Prevention of Cervical Cancer in the Republic of Macedonia, the screening was intended to cover women aged 36-45, as well as women aged 24-60 who did not have a PAP test during 2015.

Table 1 Results from the organized screening in 2016

* Percentage refers to women who received a screening invitation in 2016

\begin{tabular}{|c|c|c|c|c|c|c|c|c|c|}
\hline & \multicolumn{4}{|c|}{ Age group 24-60 } & \multicolumn{4}{|c|}{ Age group 36-45 } & \multirow[b]{2}{*}{ Total } \\
\hline & $\begin{array}{l}\text { January- } \\
\text { March }\end{array}$ & $\begin{array}{l}\text { April- } \\
\text { June }\end{array}$ & $\begin{array}{l}\text { July- } \\
\text { Sept }\end{array}$ & $\begin{array}{l}\text { Oct- } \\
\text { Dec }\end{array}$ & $\begin{array}{l}\text { January- } \\
\text { March }\end{array}$ & $\begin{array}{l}\text { April- } \\
\text { June }\end{array}$ & $\begin{array}{l}\text { July- } \\
\text { Sept }\end{array}$ & $\begin{array}{l}\text { Oct- } \\
\text { December }\end{array}$ & \\
\hline Number of invited women & 81 & & & & 654 & 232 & 206 & 356 & 1529 \\
\hline No. of returned invitations & 0 & & & & 1 & 2 & 1 & 0 & 4 \\
\hline $\begin{array}{l}\text { No. to women who have received } \\
\text { invitations }\end{array}$ & 81 & & & & 653 & 230 & 205 & 356 & 1525 \\
\hline $\begin{array}{l}\text { Received an invitation and did not call } \\
\text { for an examination }\end{array}$ & 0 & & & & 47 & 16 & 0 & 9 & 72 \\
\hline $\begin{array}{l}\% \text { Of women who received an invitation } \\
\text { but did not appear for an examination }\end{array}$ & $0.0 \%$ & & & & $7.2 \%$ & $7.0 \%$ & $0.0 \%$ & $2.5 \%$ & $* 5 \%$ \\
\hline No. on examined / performed PAP tests & 81 & & & & 606 & 319 & 447 & 464 & 1917 \\
\hline $\begin{array}{c}\% \text { Of women who received an invitation } \\
\text { and called for an examination (had a } \\
\text { Pap smear) }\end{array}$ & $100.0 \%$ & & & & $92.8 \%$ & $138.7 \%$ & $218.0 \%$ & $130.3 \%$ & $* 127.1 \%$ \\
\hline Cytologically analyzed swabs & 81 & & & & 532 & 293 & 306 & 499 & 1711 \\
\hline $\begin{array}{c}\text { Number of detected epithelial cell } \\
\text { abnormalities }\end{array}$ & 0 & & & & 9 & 4 & 12 & 48 & 73 \\
\hline $\begin{array}{l}\% \text { Of detected epithelial cell } \\
\text { abnormalities from examined women }\end{array}$ & $0.0 \%$ & & & & $1.5 \%$ & $1.3 \%$ & $2.7 \%$ & $10.3 \%$ & $4.0 \%$ \\
\hline $\begin{array}{l}\% \text { Of detected epithelial cell } \\
\text { abnormalities from cytological smears }\end{array}$ & $0.0 \%$ & & & & $1.7 \%$ & $1.4 \%$ & $3.9 \%$ & $9.6 \%$ & $4.5 \%$ \\
\hline
\end{tabular}


PARTICIPATION OF CELLULAR ABNORMALITIES IN THE TOTAL NUMBER OF CELLULAR CHANGES

ASC-US $\approx \mathrm{ASC}-\mathrm{H} \approx \mathrm{HPV} \approx \mathrm{CIN} 1 \approx \mathrm{CIN} 2$

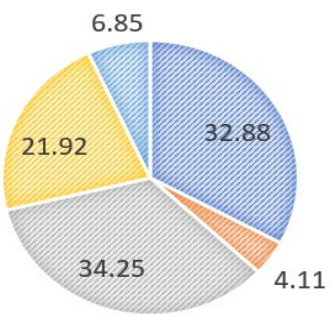

Chart 1 Discovered cell abnormalities in women aged 36-45

According to the data from the Center for Public Health in Kocani, 654 invitations were sent for screening of women aged 36-45, an age group that in 2016 was to do a PAP test according to the Program for early detection of malignant diseases in the Republic of Northern Macedonia. 5\% of those who received an invitation did not attend the examination. 1630 swabs from this age group were cytologically analyzed and 73 cellular abnormalities were detected. This means that the percentage of positive tests is 4.5 , and $95.5 \%$ of the tests are negative. Of the abnormalities detected, the most common findings are HPV, ASC - US and CIN1. 25 cases of HPV, 24 cases of ASC - US, 16 cases of CIN1, 5 cases of CIN2 and 3 cases of ASC - H. No invasive forms of cancer were detected. The percentage of cellular abnormalities is given in Chart 1.

Table 2 Results from the organized screening in 2017

\begin{tabular}{|c|c|c|c|c|c|}
\hline & \multicolumn{4}{|c|}{ Age group 46-60 } & \multirow[b]{2}{*}{ Total } \\
\hline & $\begin{array}{l}\text { January- } \\
\text { March }\end{array}$ & $\begin{array}{l}\text { April- } \\
\text { June }\end{array}$ & $\begin{array}{l}\text { July- } \\
\text { Sept }\end{array}$ & $\begin{array}{l}\text { Oct- } \\
\text { December }\end{array}$ & \\
\hline Number of invited women & 260 & 626 & 246 & 813 & 1945 \\
\hline No. of returned invitations & 2 & 1 & 0 & 0 & 3 \\
\hline $\begin{array}{l}\text { No. to women who have received } \\
\text { invitations }\end{array}$ & 255 & 625 & 246 & 813 & 1939 \\
\hline $\begin{array}{l}\text { They received an invitation and did } \\
\text { not call for an examination }\end{array}$ & 3 & 139 & 55 & 387 & 584 \\
\hline $\begin{array}{l}\% \text { Of women who received an } \\
\text { invitation but did not appear for an } \\
\text { examination }\end{array}$ & $1.2 \%$ & $22.2 \%$ & $22.4 \%$ & $47.6 \%$ & $30.1 \%$ \\
\hline $\begin{array}{l}\text { No. on examined / performed PAP } \\
\text { tests }\end{array}$ & 257 & 486 & 191 & 426 & 1360 \\
\hline $\begin{array}{l}\% \text { Of women who received an } \\
\text { invitation and called for an } \\
\text { examination (had a Pap smear) }\end{array}$ & $100.8 \%$ & $77.8 \%$ & $77.6 \%$ & $52.4 \%$ & $70.1 \%$ \\
\hline Cytologically analyzed swabs & 200 & 390 & 177 & 421 & 1188 \\
\hline $\begin{array}{c}\text { Number of detected epithelial cell } \\
\text { abnormalities }\end{array}$ & 12 & 16 & 5 & 7 & 40 \\
\hline $\begin{array}{l}\% \text { Of detected epithelial cell } \\
\text { abnormalities from examined women }\end{array}$ & $4.7 \%$ & $3.3 \%$ & $2.6 \%$ & $1.6 \%$ & $2.9 \%$ \\
\hline $\begin{array}{c}\% \text { Of detected epithelial cell } \\
\text { abnormalities from cytological smears }\end{array}$ & $6.0 \%$ & $4.1 \%$ & $2.8 \%$ & $1.7 \%$ & $3.4 \%$ \\
\hline
\end{tabular}


The screening in 2017 continues with women aged 46 to 60 years. Table 2 gives results for this age group, and doesn't include the age group of 36-45 years who in the previous year, in 2016, did not take a PAP test. According to the data from the $\mathrm{CPH}$ - Kocani, in 2017 there were no women who didn't do the screening in the previous year, but 361 PAP tests were reported, and 339 cytologically analyzed swabs. From these swabs were detected 63 cytological abnormalities or $18.6 \%$. These data are not included in the 2017 screening statistics.

During 2017, 1945 invitations were sent, of which only 3 were returned. As many as 584 or $30.1 \%$ of women who received an invitation did not attend the examination, compared to 2016 when only $5 \%$ did not attend the examination. 1360 PAP tests were performed, 1188 swabs were cytologically analyzed. Of those $3.4 \%$ are positive findings or 40 detected cellular abnormalities.

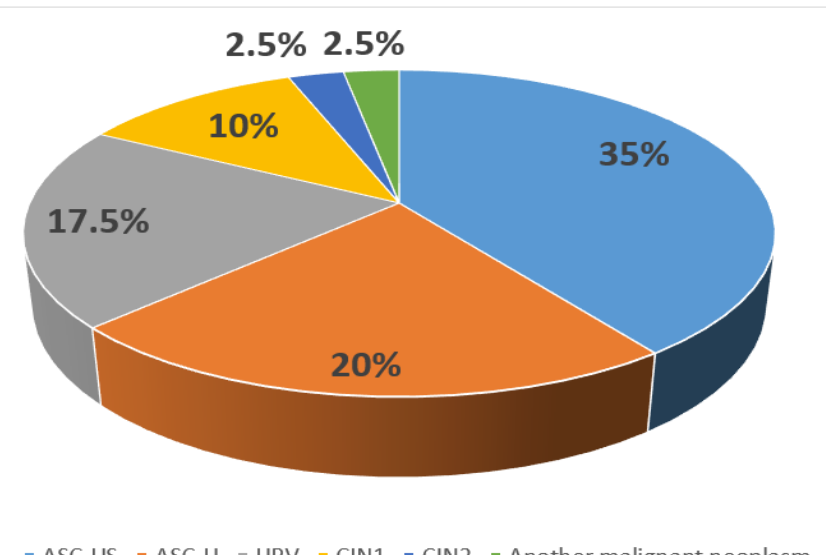

- ASC-US $=$ ASC-H $=$ HPV $=$ CIN1 = CIN2 - Another malignant neoplasm

Chart 2 Discovered cell abnormalities in women aged 46-60

From the detected abnormalities, the most common are ASC - US, 14 cases, ASC - H 8 cases where a high-risk lesion cannot be ruled out, and HPV with 7 cases. 4 swabs are positive for CIN1 and 1 for CIN2, as well as 1 positive for another malignant neoplasm. In 2017, the five most common findings are the same as in 2016, but the percentage of high-risk lesions (ASC-H) has increased.

\begin{tabular}{|c|c|c|c|c|c|}
\hline & \multicolumn{4}{|c|}{ Age group 24-35 } & \multirow[b]{2}{*}{ Total } \\
\hline & $\begin{array}{l}\text { January- } \\
\text { March }\end{array}$ & $\begin{array}{l}\text { April- } \\
\text { June }\end{array}$ & $\begin{array}{l}\text { July- } \\
\text { Sept }\end{array}$ & $\begin{array}{c}\text { Oct- } \\
\text { December }\end{array}$ & \\
\hline Number of invited women & 378 & 532 & 404 & 323 & 1637 \\
\hline No. of returned invitations & 0 & 0 & 0 & 0 & 0 \\
\hline $\begin{array}{l}\text { No. to women who have received } \\
\text { invitations }\end{array}$ & 378 & 532 & 404 & 323 & 1637 \\
\hline $\begin{array}{l}\text { They received an invitation and did } \\
\text { not call for an examination }\end{array}$ & 127 & 128 & 54 & 44 & 353 \\
\hline $\begin{array}{c}\% \text { Of women who received an } \\
\text { invitation but did not appear for an } \\
\text { examination }\end{array}$ & $33.6 \%$ & $24.1 \%$ & $13.4 \%$ & $13.6 \%$ & $21.6 \%$ \\
\hline
\end{tabular}


Jihe Zhu, Blagica Arsovska, and Kristina Kozovska

\begin{tabular}{cccccc}
\hline $\begin{array}{c}\text { No. on examined / performed PAP } \\
\text { tests }\end{array}$ & 251 & 404 & 350 & 279 & 1284 \\
$\begin{array}{c}\text { \% Of women who received an } \\
\text { invitation and called for an } \\
\text { examination (had a Pap smear) }\end{array}$ & $66.4 \%$ & $75.9 \%$ & $86.6 \%$ & $86.4 \%$ & $78.4 \%$ \\
$\begin{array}{c}\text { Cytologically analyzed swabs } \\
\text { Number of detected epithelial cell } \\
\text { abnormalities }\end{array}$ & 216 & 328 & 323 & 230 & 1097 \\
$\begin{array}{c}\% \text { Of detected epithelial cell } \\
\text { abnormalities from examined women }\end{array}$ & $2.0 \%$ & $2.2 \%$ & $3.7 \%$ & $1.8 \%$ & $2.5 \%$ \\
$\begin{array}{c}\% \text { Of detected epithelial cell } \\
\text { abnormalities from cytological smears }\end{array}$ & $2.3 \%$ & $2.7 \%$ & $4.0 \%$ & $2.2 \%$ & $2.9 \%$ \\
\hline
\end{tabular}

The screening program in 2018 covers women aged 24-35. In 2018, women aged 46-60 in 2018 who in the previous year (2017) did not have a PAP test were not invited and examined. However, the CPH - Kocani has data on 299 PAP smears and 203 cytologically analyzed swabs. Cytological analyzes revealed 2 abnormal results. 1637 women have been invited and no invitations have been returned. $21.6 \%$ of the women who received an invitation did not attend the examination, which is a decrease compared to the previous year, when $30.1 \%$ received an invitation and did not attend the examination.

The number of PAP tests examined / performed is 1284, 1097 swabs were cytologically analyzed. Of these, epithelial cell abnormalities were detected in $2.9 \%$ or 32 cases, which is a decrease compared to 2017 when the percentage of positive from analyzed was $3.4 \%$.

Chart 3 shows the detected cellular abnormalities. The highest percentage are HPV infections - 11 cases, followed by ASC-US 8 cases. The screening in 2018 revealed 3 findings of atypical glandular cells that require further investigation.

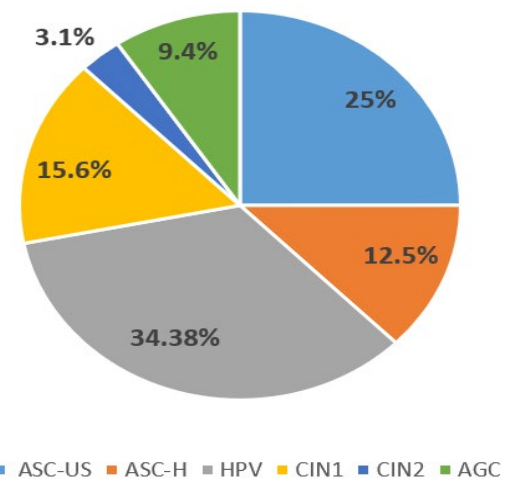

Chart 3 Discovered cell abnormalities in women aged 24-35

Table 4 Results from the organized screening in 2019

Age group 36-45

\begin{tabular}{|cccccc} 
& $\begin{array}{c}\text { January- } \\
\text { March }\end{array}$ & $\begin{array}{c}\text { April- } \\
\text { June }\end{array}$ & $\begin{array}{c}\text { July- } \\
\text { Sept }\end{array}$ & $\begin{array}{c}\text { Oct- } \\
\text { December }\end{array}$ & Total \\
\hline Number of invited women & 525 & 646 & 276 & 473 & 1920 \\
\hline No. of returned invitations & 0 & 7 & 0 & 0 & 7 \\
\hline
\end{tabular}




\begin{tabular}{|c|c|c|c|c|c|}
\hline $\begin{array}{c}\text { No. to women who have received } \\
\text { invitations }\end{array}$ & 525 & 639 & 276 & 473 & 1913 \\
\hline $\begin{array}{l}\text { They received an invitation and did } \\
\text { not call for an examination }\end{array}$ & 207 & 178 & 59 & 82 & 526 \\
\hline $\begin{array}{l}\text { \% Of women who received an } \\
\text { invitation but did not appear for an } \\
\text { examination }\end{array}$ & $39.4 \%$ & $27.9 \%$ & $21.4 \%$ & $17.3 \%$ & $27.5 \%$ \\
\hline $\begin{array}{l}\text { No. on examined / performed PAP } \\
\text { tests }\end{array}$ & 318 & 461 & 217 & 391 & 1387 \\
\hline $\begin{array}{l}\% \text { Of women who received an } \\
\text { invitation and called for an } \\
\text { examination (had a Pap smear) }\end{array}$ & $60.6 \%$ & $72.1 \%$ & $78.6 \%$ & $82.7 \%$ & $72.5 \%$ \\
\hline Cytologically analyzed swabs & 244 & 426 & 165 & 349 & 1184 \\
\hline $\begin{array}{l}\text { Number of detected epithelial cell } \\
\text { abnormalities }\end{array}$ & 14 & 38 & 12 & 12 & 76 \\
\hline $\begin{array}{l}\text { \% Of detected epithelial cell } \\
\text { abnormalities from examined women }\end{array}$ & $4.4 \%$ & $8.2 \%$ & $5.5 \%$ & $3.1 \%$ & $5.5 \%$ \\
\hline $\begin{array}{l}\text { \% Of detected epithelial cell } \\
\text { abnormalities from cytological smears }\end{array}$ & $5.7 \%$ & $8.9 \%$ & $7.3 \%$ & $3.4 \%$ & $6.4 \%$ \\
\hline
\end{tabular}

The screening in 2019 is conducted for women aged 36-45 years. The data do not include women who took the PAP test in 2018. In 2019, the number of invited women is 1920 , the number of returned invitations is 7 . The number of women who received an invitation but did not appear for an examination is 526 or $27.5 \%$, showing an increase compared to the previous year. 1387 PAP tests were performed and 1184 swabs were analyzed. Cytological abnormalities were found in $6.4 \%$ or 76 findings.
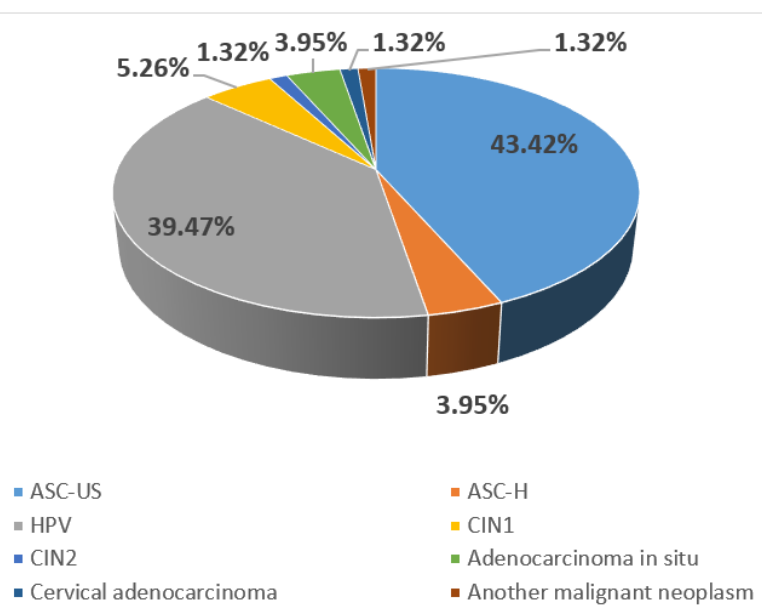

Chart 4 Discovered cell abnormalities in women aged 36-45

The most common findings are ASC - US with 33 cases, 30 cases with HPV, 3 findings with ASC - H and adenocarcinoma in situ. 4 findings of CIN1 and 1 CIN2 each, cervical adenocarcinoma and other malignant neoplasm. In 2019, in the age group of 36-45 years, the finding of invasive lesions increased compared to the screening in 2016, when there were no invasive forms in the detected cellular abnormalities. 


\begin{tabular}{|c|c|c|c|c|c|}
\hline \multicolumn{6}{|c|}{ Table 5 Results from the organized screening in 2020} \\
\hline & \multicolumn{4}{|c|}{ Age group 46-61 } & \multirow[b]{2}{*}{ Total } \\
\hline & $\begin{array}{l}\text { January- } \\
\text { March }\end{array}$ & $\begin{array}{l}\text { April- } \\
\text { June }\end{array}$ & $\begin{array}{l}\text { July- } \\
\text { Sept }\end{array}$ & $\begin{array}{l}\text { Oct- } \\
\text { December }\end{array}$ & \\
\hline Number of invited women & 665 & 373 & 125 & 199 & 1362 \\
\hline No. of returned invitations & 3 & 0 & 0 & 0 & 3 \\
\hline $\begin{array}{l}\text { No. to women who have received } \\
\text { invitations }\end{array}$ & 662 & 373 & 125 & 199 & 1359 \\
\hline $\begin{array}{l}\text { They received an invitation and did not } \\
\text { call for an examination }\end{array}$ & 258 & 107 & 13 & 36 & 414 \\
\hline $\begin{array}{l}\% \text { Of women who received an invitation } \\
\text { but did not appear for an examination }\end{array}$ & $39.0 \%$ & $28.7 \%$ & $10.4 \%$ & $18.1 \%$ & $30.5 \%$ \\
\hline No. on examined / performed PAP tests & 405 & 266 & 112 & 127 & 910 \\
\hline $\begin{array}{c}\% \text { Of women who received an invitation } \\
\text { and called for an examination (had a } \\
\text { Pap smear) }\end{array}$ & $61.2 \%$ & $71.3 \%$ & $89.6 \%$ & $63.8 \%$ & $67.0 \%$ \\
\hline Cytologically analyzed swabs & 277 & 214 & 71 & 133 & 695 \\
\hline $\begin{array}{l}\text { Number of detected epithelial cell } \\
\text { abnormalities }\end{array}$ & 15 & 13 & 5 & 8 & 41 \\
\hline \multicolumn{6}{|l|}{$\begin{array}{l}\% \text { Of detected epithelial cell } \\
\text { abnormalities from examined women }\end{array}$} \\
\hline $\begin{array}{l}\% \text { Of detected epithelial cell } \\
\text { abnormalities from cytological smears }\end{array}$ & $5.4 \%$ & $6.1 \%$ & $7.0 \%$ & $6.0 \%$ & $5.9 \%$ \\
\hline
\end{tabular}

In 2020, 1362 women aged 46-61 were called for screening, and only 3 invitations were returned. 414 women received an invitation, but did not respond to the examination or in percentages of $30.5 \%$, which is the highest percentage during the 5 years from 2016-2020 when the screening was organized. 910 PAP tests were performed, of which 695 were cytologically analyzed, during which 41 cell abnormalities were detected, ie $5.9 \%$ of the analyzed swabs.

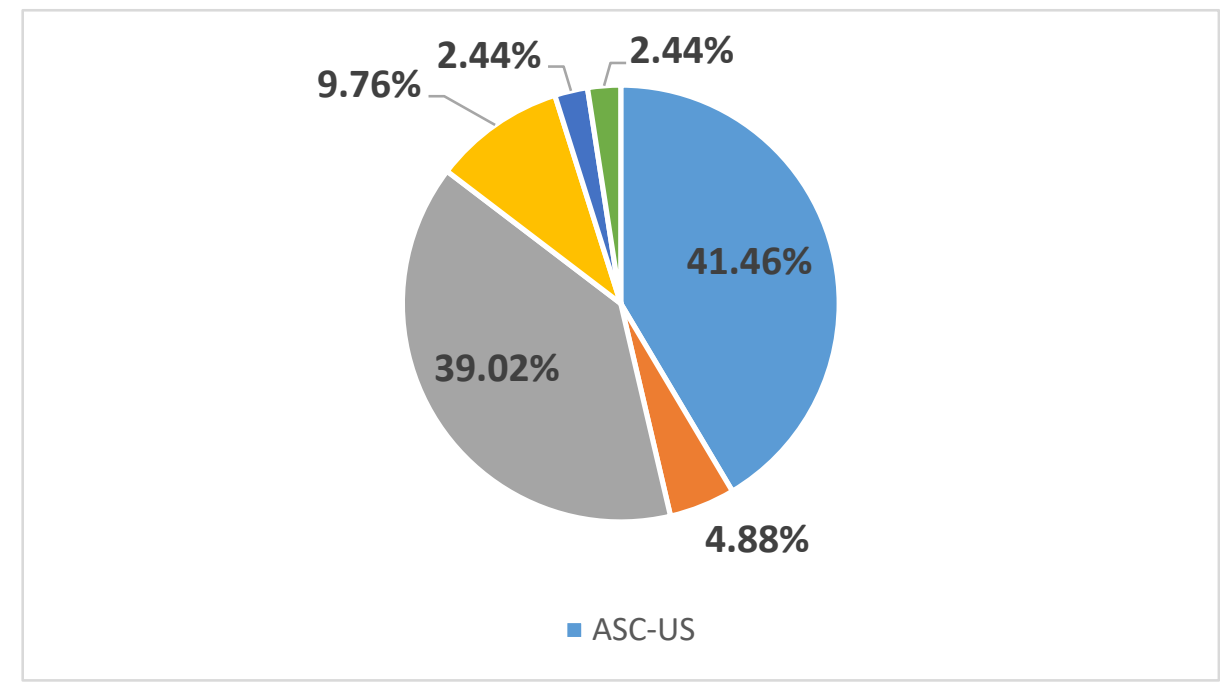

Chart 5 Discovered cell abnormalities in women aged 46-61 
Chart 5 shows the percentage of individual abnormalities out of the total detected cellular abnormalities. Most, with $41.46 \%$ or 17 findings for ASC - US, 16 for HPV and 4 findings CIN1. The other abnormalities shown in the graph are present in a smaller percentage, and no invasive forms or cancer are detected.

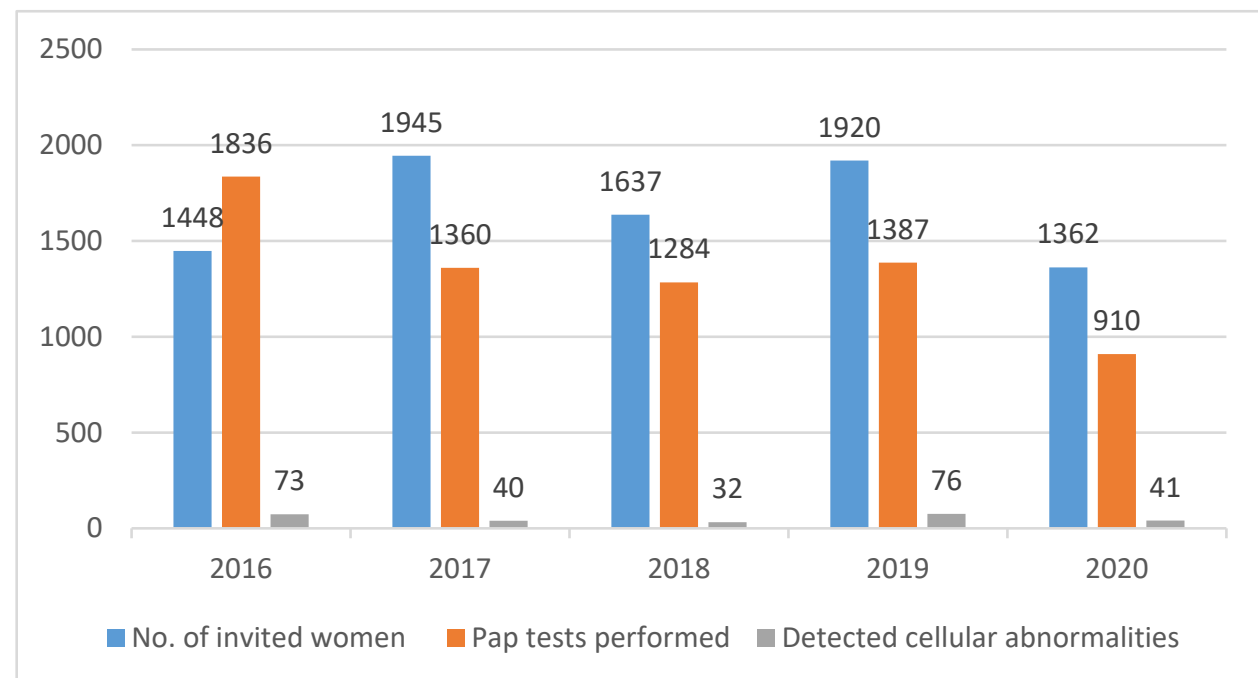

Chart 6 Review of the number of invited women, PAP tests made and discovered cell abnormalities during the 5 years of cervical cancer screening

Chart 6 shows that the highest number of invited women was in 2017 and the lowest in 2020. Most PAP tests were performed in 2016 and the least in 2020. The small number of invited women and PAP tests performed in 2020 may be due to of the epidemiological situation with the Covid19 pandemic. Table 5 shows that the percentage of women who received an invitation but did not respond to an examination $(30.5 \%)$ is the highest in 2020 , which is probably due to the fear of patients with coronavirus infection, postponing all examinations that are not urgent, insulation and quarantine, etc.

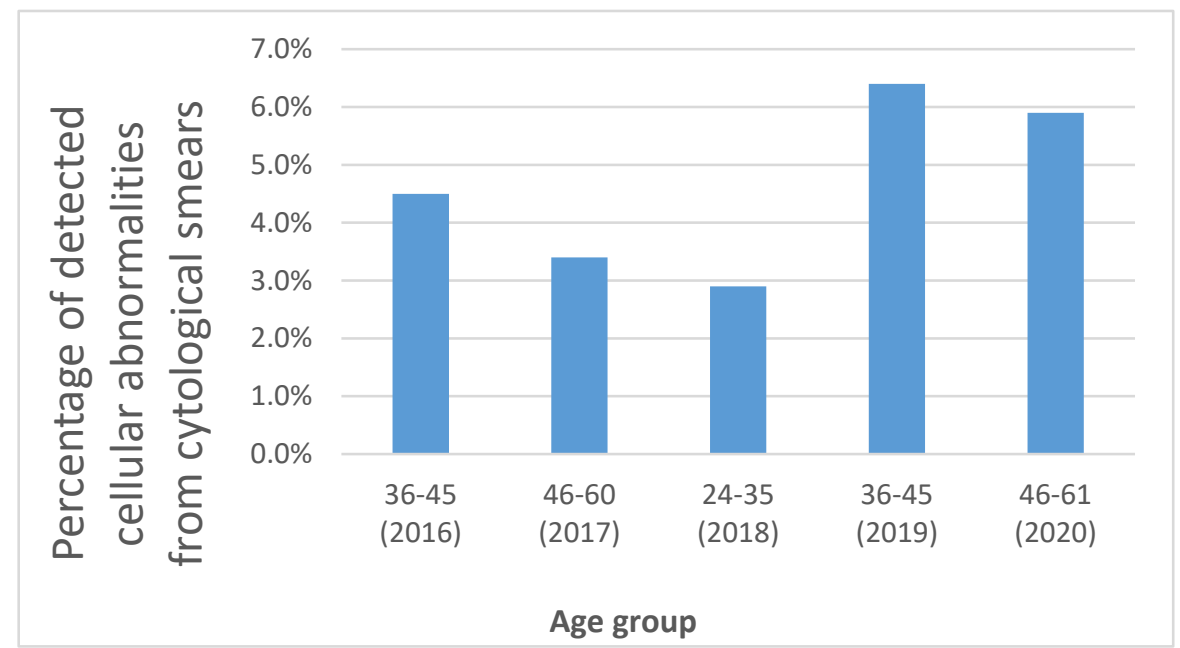

Chart 7 Representation of the percentage of discovered cell abnormalities according to the age group 
According to the results from the screening conducted during 5 years, from 2016 - 2020 on the territory of Kocani, Vinica, Berovo, Pehchevo and Delchevo, the highest percentage of epithelial cell abnormalities were detected in the age group of 36-45 years according to PAP tests performed in 2019.

\section{Ambulatory and dispensary morbidity from 2011-2020}

Diagnosis of cervical cancer is indicated by the code C53 - Malignant neoplasm of the cervix of the uterus. The following tables show the percentage of this diagnosis among the female population on the territory of Kocani, Vinica, Berovo, Pehchevo and Delchevo, in a period of 10 years.

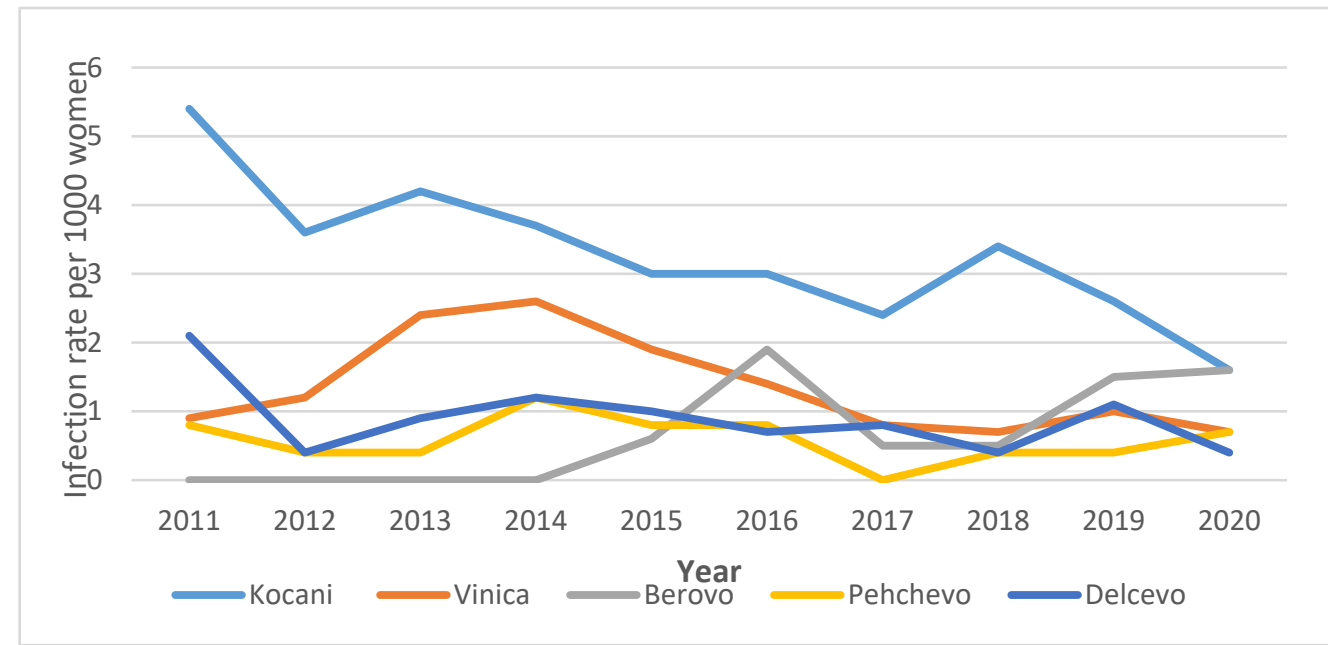

Graph 8 Display of the morbidity rate per 1000 women throughout 10 years

On Graph 8 can be seen that per 1000 women, most infected are in Kocani during the period of all 10 years. In 2011, that number was the highest 5.4 / 1000 or expressed as a percentage of $0.54 \%$ of the total number of women. That trend has declined, so the lowest rate is in 2020, ie. 1.6 / 1000. The number of patients in Vinica has been declining since 2014, when the rate was highest at 2.6. The curve for Pehchevo and Delchevo has numerous fluctuations, while for Berovo until 2014 there is no information, following the curve recording two peaks and increasing from 2019. The $\mathrm{CPH}$ - Kocani has no data on the number of women who died from the disease and the mortality rate.

Charts 9 and 10 show that most cases of malignant neoplasm of the cervix are in the age group of 50-54 years in terms of the total number of diagnosed cases and in relation to the total number of women of that age in 2011. Diagnosed cases in the age group of 25-34 years are detected every year only in Kocani, except for 2019 and 2020 and one case in Berovo in 2017. 


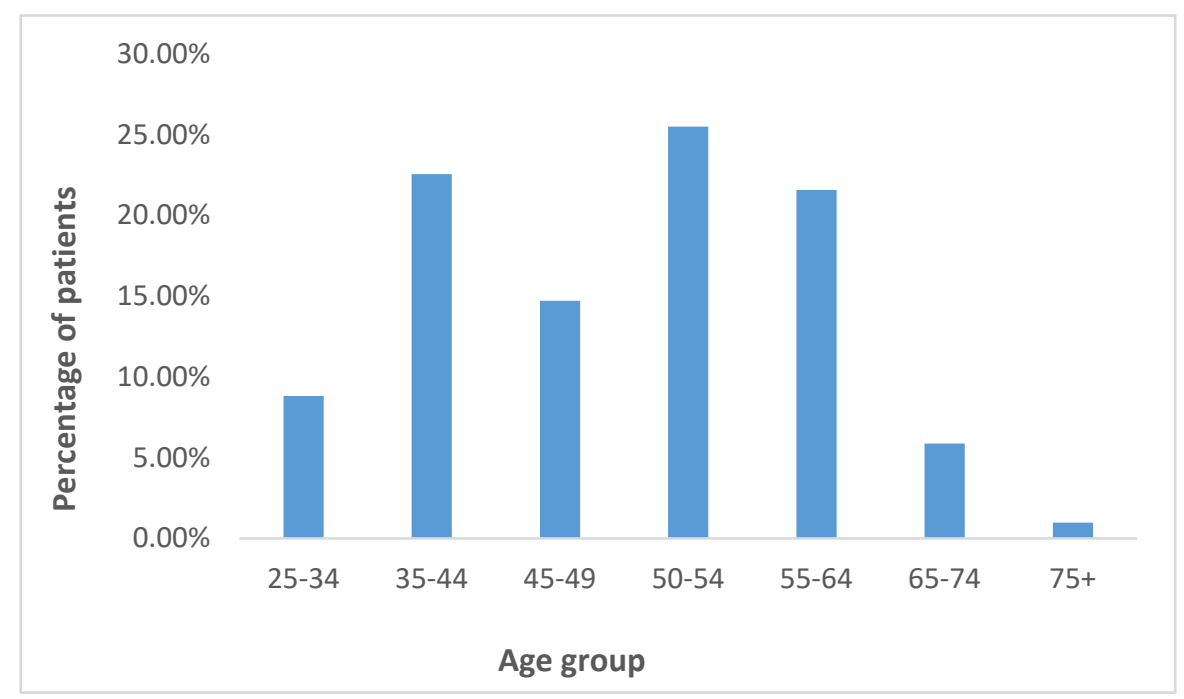

Chart 9 Percentage of patients by age in relation to the total number of cases

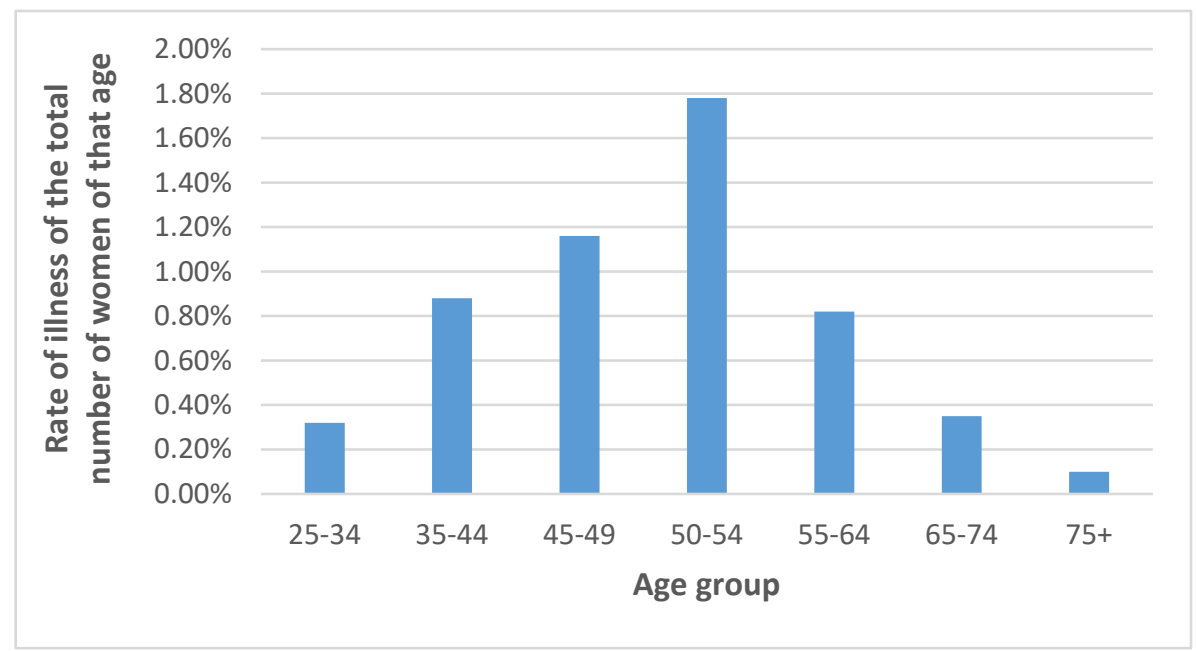

Chart 10 Rate of ill woman in relation to the total number of women on that age

\section{CONCLUSION}

Cervical cancer remains one of the most common malignancies in the female population and in the world in general. Most new cases occur in developing countries, probably due to insufficient resources for prevention. In addition to most risk factors, persistent HPV infection is considered to be the main cause of the changes. The cervical cancer is potentially the most preventable and curable. Primary prevention consists of the HPV vaccine for the most common high-risk types of the virus, and secondary screening for PAP tests.

According to the results of the research, in Macedonia, the coverage of screening should be increased and the registration should be regulated. In the early stages, the disease does not give any symptoms and therefore screening is extremely important. 


\section{REFERENCES}

Aref-Adib, M., Freeman-Wang, T., (2016). Cervical cancer prevention and screening: the role of human papillomavirus testing. The Obstetrician and Gynaecologist. 18:251-63. Retrieved from https://doi.org/10.1111/tog.12279

Bansal, A., Singh, M., Rai, B. (2016). Human papillomavirus-associated cancers: A growing global problem. International journal of applied and basic medical research. 6(2): 84-89. Retrieved from https://doi.org/10.4103/2229516X.179027

Barek, C. J. (2011). Gynecology of Berek and Novak. Tabernacle. Skopje

Barret, K. E., Barman, S. M., Boitano, S., Brooks, H. L. (2012). Ganong's review of Medical Physiology. 24th edition. The McGraw - Hill Companies, Inc.

Burd, E. M., (Jan., 2003). Human Papillomavirus and Cervical Cancer. American Society for Microbiology. 16(1): 1-17. Retrieved from https://doi.org/10.1128/CMR.16.1.1-17.2003

Dimitrov, G., Sterjovska - Aleksovska, A., (2013). Authorized lectures. Faculty of Medical Sciences. University "Goce Delcev", Stip

Hurt, K. J., Guile, M. W., Bienstock, J. L., Fox, H. E., Wallach, E. (2010). The Johns Hopkins Manual of Gynecology and Obstetrics. 4th edition. Lippincott Williams \& Wilkins

Jovanovski D., Maneva-Kostovska, L., Anastasova-Nikolova L., Smickoska, S., Krstevska, V., (2002) Radiotherapy oncology. University "St. Cyril and Methodius "- Skopje

Kumar, V., Abbas, A. K., Aster, J. C. (2015). Robbins and Cotran Pathologic basis of disease. 9th edition

Ministry of Health of the Republic of Northern Macedonia. Guidelines for practicing evidence-based medicine; Gynecology and Obstetrics

Mladenovic, D. Et al. (2008). Gynecology and Obstetrics. Office for Ujbenike, Belgrade

Palchevski, G. (1981). Gynecology and Obstetrics. Medical Faculty - Skopje 